\title{
Informatics as a particular field of education
}

\author{
PÉTER SZLÁvi and LÁSZló ZSAKó
}

\begin{abstract}
Informatics education can be discussed at various levels. There is informatics education at the university, there is professional informatics training and there is public informatics education. In the following article we are going to deal with the latter, that is we are going to discuss what areas of informatics should be introduced to students within the frame of the informatics subject in primary and secondary education.

Knowledge in connection with informatics can be grouped from different points of view. We consider the following points to be acceptable: according to scopes of knowledge. $[1,2]$
\end{abstract}

Key words and phrases: teaching informatics, national curriculum, fields of Informatics.

ZDM Subject Classification: B12, B13, B14, Q12, Q13, Q14, Q82, Q83, Q84.

\section{Introduction}

Informatics education is viewed variously in the world. There are countries, France for instance, where informatics is not a compulsory subject at schools, but it can be studied as optional and students can choose to enter for a school-leaving examination in it. $[3,4,13]$

In other countries informatics is a compulsory subject in primary and secondary education. However, it may greatly vary in content and the number of classes per week.

This article is not aimed at discussing whether informatics should be a compulsory school subject for everybody. Our main goal is to consider the suitable and practical content of this subject when there is some kind of decision on having 
informatics in the curriculum. This article is meant to be an opening speech of a debate and to start some brainstorming in this topic.

In the article we are attempting to sum up what we consider to belong to each part of knowledge. First and foremost we set up aims and refer to the relationships with other fields. The following scopes of knowledge are going to be dealt with:

A. Algorithmization, data modelling, programming (we always execute algorithms in our everyday life and at school, as well, fill in data structures - questionnaires, forms -, we design activity sequences, information flow processes. To be able to understand all these we need to know the basis of these processes.

B. The tools of programming (it includes the use of all the language and other tools that are necessary for testing, realising algorithms and data models).

C. Solving application tasks with the help of computers (the question of how to solve everyday problems with the help of informatics should be dealt with: constructing graphic images and objects, word processing, spreadsheeting, database management, presentation, etc.).

D. Management of application systems (application knowledge and the ability to handle rapidly outdating tools should be separated although they should be taught in parallel).

E. Computer-assisted problem solving (here it is recommended to start from the problems emerging - e.g. a class excursion has to be arranged -, first it should be dealt with as an organizational task, then the necessary tools should be found to match each part of the task - not all of which are necessarily informatics tools - and if needed, new tools should be created, etc.).

F. Infocommunication (it is recommended to be aware of the influence of communication technology on the society, to adjust to changes and to use infocommunication tools properly).

G. Operation principles and application of informatics tools (there are numerous types of hardware and software devices, and every computer user should acquire the knowledge of their proper use).

H. The mathematics of informatics (certain mathematical knowledge which form the basis of informatics knowledge is either not included in mathematics as a subject or not at the phase when it is needed - e.g. mathematics does not deal with the matrix but it is important to understand the everyday usage of 
the matrix before studying spreadsheeting -, which is not necessarily wrong. However, it means that informatics should deal with these questions).

I. Informatics and society (it is worth studying the history of informatics as part of our culture, dealing with the prospective development of informatics, examining its current influence on the society, data security, data protection, the ethic issues of informatics application).

\section{A short overview of other countries' ideas}

We consider it important to separate paragraphs $\mathbf{A}$ from $\mathbf{B}$ and $\mathbf{C}$ from $\mathbf{D}$, respectively, when defining the scopes of knowledge only, but in every sort of teaching conception they are closely linked together, thus should be taught simultaneously.

The only reason why we separate them here is that we intend to refer to fast that paragraphs $\mathbf{A}$ and $\mathbf{C}$ contain primary knowledge, where the knowledge of the tools is secondary knowledge. It is well-known that the knowledge of tool-assisted problem solving skills is superior to the 'technical' knowledge of how to handle these tools.

The scope of knowledge described in $\mathbf{E}$ is not to be taught separately either; it is the summary of $\mathbf{A}$ and $\mathbf{C}$ at a higher level: we start from the problem itself and we choose a tool $(\mathbf{C})$ or we create a tool $(\mathbf{A})$ to solve the problem.

This article does not aim at making a detailed comparison of national curricula, so we would just like to point to the notions of some countries.

Informatics education in Austria is fairly similar to the one in Hungary, [8, 9] but much more emphasis is put on programming. In addition, there is a new feature included compared to the Hungarian curriculum i.e. an application area of informatics e.g. industry, administration or medicine, is also presented.

In Thüringen (Germany) the informatics curriculum, which seems more theoretical as compared to the Hungarian one, is characterized with a higher proportion of programming material [10].

In the Netherlands informatics is grouped around 4 main areas: data processing and communication, data processing systems, applications, information society $[11]$.

The English National Curriculum $[12,15]$ uses a basically different grouping categories: findings things out; developing ideas and making things happen; exchanging and sharing information; reviewing, modifying and evaluating work 
as it progresses; breadth of study. As one can see, here it is not the fields of informatics that are listed but more general pedagogical notions, which abstract from any concrete applications or tools. Though the details quite coincide, there is one more important characteristics i.e. applications are considered much more important than the knowledge of tools. Interestingly enough, the keywords of the requirements at the GCSE exams are as follows: information technology, numerical applications, co-working, individual study and presentation, problem solving.

\section{Fields of Informatics}

\section{A. Algorithmization, data modelling, programming elements}

We learn to understand the world around us with the help of models. Programming can be a useful way of developing modelling ability, making students think logically. Because it has to be formalized, it requires a precise, exact way of thinking. The scene of formalization in program composition is data modelling and algorithmization, thus elements connected to these should be taught here. Formalization should be extended with care: using examples, notions that are appropriate to the age group. We regard it very important to lay emphasise on this in education from the beginning (e.g. it will be regarding the improvement of abstraction skills, or concerning the effectiveness of the use of computers).

First, algorithmization is not about computer-assisted execution. In most of the cases, the person who created the algorithm can perform it in his mind as well. It is only then that an automatic machine, the computer, can be made to process the precisely constructed algorithm.

The aim of the application of the computer is to create (new) output data from the input data with the help of programs. That is why teaching data structures and algorithms cannot be separated.

The point is that students should realize that the basis of computer-assisted problem solving is algorithm elaboration (and not coding)! However the knowledge of programming language is required to reach this, because programming cannot effectively be taught from books only, students need to try their programs on the computer as well. We would like to note that teaching the programming language should not be the primary aim in studying programming. [5]

It is important for the students to get acquainted with traditional programming structures independently of programming languages. Therefore this scope 
of knowledge describes computer-assisted problem solving as tool improvement, where the problem solving tool (the program) should be created.

\section{B. The tools of programming}

To execute and test algorithms we need certain computer tools with the help of which we can describe problem solving, we can test it on the computer, check its correctness and quality. These are as follows: algorithm describing tools, programming languages, testing, tracing, error detection tools and systems.

Their application belongs to the tasks described under the previous paragraph; there is no need to deal with them separately in public education. Thus a programming language should be taught to the extent which is necessary for the realization, testing of algorithms but the language is not in the centre of the informatics curriculum.

When selecting programming languages, it is recommended to find one that makes it possible to solve problems which are interesting to the given age group in a simple way. [6]

\section{Solving application tasks with ready-made program systems}

This scope of knowledge emphasizes computer application from the point of view of the problem and the question is whether - the given - general program can be used for problem solving or not (rather than the way how it can be used).

We do not concentrate on the tool: the computer or the software. Within the frames of Informatics tools it is the hardware, while in the Application systems and Informatics tools (that is operating system as program system) part it is the software that is focused on. There is a similar idea in the Computer-assisted program solving scope of knowledge as well, but while there the choice is made on the basis of the ability of the 'whole' computer, here the software applied is fixed and only its 'philosophy' is to be studied.

We rely on the knowledge of certain notions, skills that belong to other scopes of knowledge. Thus the existing or developing ability of algorithmic thinking is a definite advantage (this is meant to be developed within the scopes of knowledge in Algorithmization, Data modelling and in The mathematics of informatics).

As it has become evident from the facts mentioned above, the teaching material of this scope of knowledge does not exclusively belong to informatics as a subject. There are certain important areas that seem clear today, but their number can be increased with the rapid development of informatics: 
- word processing: compilation of text documents, publications in traditional and electronic form;

- constructing graphic images and objects: constructing and processing diagrams, graphic figures, photos;

- spreadsheeting: arranging data in a table, making calculations;

- database management: storing, arranging, grouping data, making reports;

- presentation: making presentations, electronic notice boards, billboards

- multimedia design: designing video and audio files, animation.

Many different subject areas should be considered in order to draw up the problems. The many areas of application at a higher level can be studied within the subject informatics. Handling knowledge should be included in a certain subject if the tool is closely linked to a special profession (e.g. CAD).

In this case the stress is on the usage of the tool: the program, as a tool is used to solve the task.

\section{Application system management}

The principles for teaching general application systems (word processors, image, text, sound editors and music composers, spreadsheets, database managers) and professional application systems (CAD, expert systems, etc.) are the same as mentioned in connection with the tools of programming. As it is the 'logic' (abstract) aspect of problem solving by program writing that prevails scope of knowledge within Algorithmization, data modelling, and the tool (manual) aspect in The tools of programming, there is a similar pair formed by the previous (Application task solving ...) and this set of knowledge as well. Apart from specialised classes, public education does not aim at teaching these systems in details. This means that they should not be placed in the centre of the curriculum; the curriculum should not be based on the menu list of these systems.

According to the problems listed in the previous paragraph, practically, students should study word processing, database management, with the help of which they have to solve their tasks in the course of their studies, thus what they need to acquire is the functions essential for this (there is need to confirm the correctness of their activities here as well, just like in algorithmization). 
In word processing, for instance, they should be taught how to create the text documents characteristic of their age group, while the tool itself does not form a central part in the informatics curriculum.

\section{E. Computer-assisted problem solving}

There are a number of problems at school, in certain special subjects, in everyday life that can and should be solved with the help of a computer. In this chapter we observe these tasks from a different starting point than in chapters A and C. First and foremost, we talk about tool selection, tool list and tool recognition.

At first, students have to realise that the problem or certain parts of it can be solved with the tools of informatics. Then they have to select the most appropriate tool or tools (equipment, program, program system) to solve the problem. In case the tool does not exist, they have to create one (programming task). When using more than one tool, they have to solve the problem of information transfer between the tools. If the tool to be used is unknown, they have to put it into use with the help of the documentation.

We do not intend to give new information, but to solve a problem with the existing informatics knowledge. The first step towards the solution is the selection of the tool to be used. It can be a target program written earlier (professional training programs at schools are like this), or students can write a new program on the basis of their knowledge and with the help of their teachers. Consequently, the stress is on the usage of 'complex' informatics knowledge.

Regardless of the exact case, what students should realize is that the computer can be used for many different problems. They should learn how to use the computer for different purposes, and what amount of labour is required in the course of studying this scope of problems.

Because of its character, in this scope of knowledge teamwork can be applied very well, enabling the students to work in the structure that they will have at their future work places (cf. everybody does a different part of the task, but it works well together). However, this possibility breaks down the traditional education system; this type of activity cannot be practised during lessons, sometimes not even within the traditional frames of school. In spite of this, it creates a closer 
relationship between students and the teacher, school and the traditional system of homework in other subjects.

\section{F. Infocommunication}

In the second half of the 90's there were two areas that were developing very fast and they became more and more related to each other during this process. One of them is the Internet, the other is mobile communication. The scope of knowledge entitled Infocommunication covers the topic of how they are entwined.

There are two types of activities on the Internet. In the first we can give information that can be reached by many people at different times, in different ways. Home pages, access to remote databases, information systems, downloading from remote computers, etc. are included here. Giving and searching for information play an important part, therefore the conscious arrangement of the information, which makes it easier to apply it later, and the development of effective information search techniques are essential.

In the other type of activities we can communicate with other people, which can be two-sided like in electronic mail system, in telephoning, video telephoning; or many-sided like using mailing lists, chatting or video conference systems, etc.

The mobile phone is not only a simple, portable telephone but it is an intelligent device that can also be used for mailing (sms), multimedia mailing (mms), browsing on home pages (wap). ${ }^{1}$

Either tool or activity is concerned, communication is always there beyond tool application.

\section{G. Informatics tools}

The hardware and software tools of informatics can hardly be separated by most of the students, because they use the physical tools through the application programs (operation systems, network systems, etc.). Cultural basis does not require the in-depth knowledge of their physical structure or operation; students have to learn the way to apply them.

Only general system knowledge regarding the structure and operation of the tools is necessary, on the basis of which teachers can answer students' question about the tools (e.g. how the mouse works, are allowed to look into the light pen,

${ }^{1}$ If it did not have a traditional name, it could as well be called a computer. 
can a floppy disk be bent, what the difference is between a matrix printer and a laser printer, etc.).

Concerning the possibility of connecting the tools, the question to be discussed can be based on the difference between devices sending and receiving analogue or digital signals, and on the understanding of the signal transformer to be applied in between.

The knowledge concerning the structure and operation of the computer and its peripheral devices is not included in Informatics, because we believe that it belongs to the area of Technology, as a scope of knowledge. Obviously, it does not necessarily mean that it must be taught within the frames of the subject technology, because of the limited number of lessons and partly, because in many schools there are no separate subjects for informatics and technology. Thus at present, most of the knowledge mentioned belongs to the Informatics subject.

\section{H. Mathematics of informatics}

This includes mathematical knowledge, which is both necessary for the understanding of the basis of informatics and is considered to be the easy-to-understand mathematical applications of informatics. We have selected elements in our list which are excluded from mathematics or although they are included but not at the right phase or not in proper depth for informatics.

There are a number of things in mathematics that are necessary for studying informatics. Our list includes the following: sets, logical assertion, relations, and the algorithmization of the four rules of arithmetics. In an extreme case the problem of vectors, matrixes can also be included. During mathematics studies, students learn about sequences, a generalization of which can be the matrix. Continuing from this, students can be taught the concept of the matrix either within mathematics or within another subject. However, it is very important to teach students certain mathematical concepts that are essential for using different application programs (spreadsheeting, graphic programs, etc.).

We believe that they should be taught within the boundaries of the independent Informatics subject. 
Informatics raises practical problems, which are easy to understand, apparent and may also be interesting for the students. This would make students acquire new information by learning about certain true-to-life mathematical problems.

\section{Informatics and society}

It is the process of how computers are integrated into our world. The tendency is that in the past only experts could use computers, while in the future it will require only general knowledge.

It is worth dealing with the history of informatics, computer science. This information can be used to make the process of education more colourful, or to explain certain concepts (why did it happen this way?). We do not believe that all the information should be taught in one unit. It is more effective to divide it into smaller parts and include them in the lesson in 5-10-minute units from time to time.

Beside the past, it is very important to examine the present potentials as well. Student can get acquainted with the everyday applications of informatics in our life (barcode reading cash registers, savings books with data cells, computer readable credit cards, etc.). Teachers should draw students' attention to the fact how computers change our life.

After the present, we should deal with the future as well. Teachers should look over the predictable, perceivable prospects of informatics, drawing up the possible roles in the future (nowadays!).

The emerging ethic and psychological questions within informatics are also to be covered.

Students have to be warned about the rules of data protection, data storage and the dangers of using informatics systems.

\section{The purpose of public informatics education}

One result of the above can be the definition of the purpose of informatics education, which is summarized as follows:

- up-to-date user skills (training students who can utilize the possibilities of the computer, informatics culture);

- algorithmic thinking (a function, similar to mathematics, of developing thinking, which is essential at school and in everyday life as well); 
- independent work (the computer as a device reacting directly to the student's work opens up new opportunities for students to study at their own rate, for the teacher to deal with talented students individually, etc.);

- interoperability, teamwork (solving more serious computer tasks requires teamwork, it is necessary to divide the tasks into smaller units, to keep in touch with the others);

- creative work (whether we are writing a program, or creating a text document or a database on the computer, the result is a product, with all the consequences of 'being a product');

- realization of the interrelationship between informatics and society (the rapid development of informatics will change the society radically, and in this rapidly changing world only those who understand the changes and their reasons can feel at home).

Valentina Dagiene [7] has a very similar summary of the aims of informatics education in Lithuania.

\section{Instead of a Conclusion}

From September 2004 The Government of the Hungarian Republic introduced the new National Curriculum, in accordance with which informatics is supposed to be taught in the following number of classes:

\begin{tabular}{|l|c|c|c|c|c|c|c|c|c|c|}
\hline Year & 3 & 4 & 5 & 6 & 7 & 8 & 9 & 10 & 11 & 12 \\
\hline Number of classes & 1 & 1 & 1 & 1 & 2 & 2 & 2 & 2 & 2 & 2 \\
\hline
\end{tabular}

The content of the obligatory informatics subject has mainly been based on the ideas outlined in the above article.

\section{References}

[1] Zsakó László, Az informatika ismeretkörei (The Scopes of Knowledge in Informatics), ELTE TTK Informatikai Tanszékcsoport, 2002.

[2] Zsakó László, Teaching Informatics in Hungary, The IOI'96 NewsLetter (1995), no. 2, 5-6, no. 3, 5-6, no. 4, 5-6.

[3] Körösné Mikis Márta, Informatika érettségi Franciaországban (The National Curriculum for France), Inspiráció (2002), no. 1, 11-12. 
[4] Règlement de l'épreuve. Académie de l'Ile de France. Note du 22 aout 1997 - Bulletin Officiel du ministère l'Education Nationale No 30 du 4 septembre 1997.

[5] Harangozó Éva, Szlávi Péter, Zsakó László, Joining programming theorems - a practical approach to program building, Annales Universitatis Scientiarum Budapestinensis, Sectio Computatorica, Budapest (1996), 155-173.

[6] Szlávi Péter, Zsakó László, Programozási nyelvekkel kapcsolatos fogalmak (Some Basic Concepts on Programming Languages), Inspiráció 4-5, no. 1-4 (1996-1997).

[7] Valentina Dagiene, Problems of Teaching Logo as a Part of Informatics, EUROLOGO '97 - Sixth European Logo Conference, Budapest (1997), 225-233.

[8] Grundzüge der Informatik, Informatika tankönyv, Austria, 2003.

[9] Berlinger Natasa, Az informatika oktatása Ausztriában (Teaching Informatics in Austria), Inspiráció (2004), no. 4-5, 28-31, (2005), no. 1, 16-19.

[10] Andor Gergely, Informatika oktatás a németországi Türingia tartományban és összehasonlítása a magyar Nemzeti Alaptantervvel, Inspiráció (1999), no. 6, 16-20, (2000), no. 1, 25-29.

[11] Erdők Zsuzsanna, A holland középiskolai informatika oktatásáról (Teaching Informatics in the Netherlands), Inspiráció (2005), no. 3, 16-21.

[12] Körösné Mikis Márta, Informatika oktatás Angliában (Teaching Informatics in Great Britain), Inspiráció (2001), no. 6, 10-13.

[13] Körösné Mikis Márta, Informatika oktatás Franciaországban (Teaching Informatics in France), Inspiráció (2001), no. 6, 13-15.

[14] Körösné Mikis Márta, Informatika érettségi Angliában (The National Curriculum for England), Inspiráció (2002), no. 1, 9-11.

[15] The National Curriculum for England: Information and Communication Technology, Qualifications and Curriculum Authorithy, London, 1999.

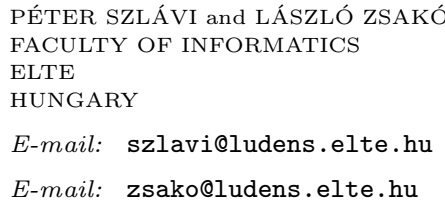

